\title{
Morphological, Physiological, and Anatomical Characteristics Associated with Heat Preconditioning and Heat Tolerance in Salvia splendens
}

\author{
Seenivasan Natarajan \\ Mid Florida Research and Educational Center, Institute of Food and Agricultural Sciences, \\ University of Florida, Apopka, FL 32611
}

\author{
Jeff S. Kuehny ${ }^{1}$ \\ Louisiana State University AgCenter, School of Plant, Soil, and Environmental Science, Baton Rouge, \\ LA 70803
}

\begin{abstract}
AdDitional INDEX wORDs. thermotolerance, photosynthesis, transpiration, morphology, bedding plants, HSPs, heat shock proteins, stomata, stress

Abstract. Many bedding plant cultivars struggle to survive in high temperatures during production. The objective of this research was to study how heat stress and preconditioning affects growth, physiology, and anatomy of the annual bedding plant Salvia splendens Ker Gawl. Heat preconditioning increased the quality and survival capacity of nonheat-tolerant 'Sizzler Red'. Heat-tolerant traits of 'Vista Red' were enhanced with preconditioning. The higher tolerance levels with and without heat preconditioning for 'Vista Red' suggested that cultivars with thicker, broader leaves, and higher stomatal frequency had higher light interception, gas exchange, transpirational cooling, and $\mathrm{CO}_{2}$ fixation. These plants attained a more rapid canopy cover and maintained healthier leaves and supplied photoassimilates to reproductive development and root growth. Selecting for these characteristics could be used to help provide guidelines for breeding and selection of heat-tolerant salvia.
\end{abstract}

Bedding plant production for residential and commercial landscaping has become the most important part of the floriculture industry (U.S. Department of Agriculture, 2007). At a wholesale value of $\$ 1.79$ billion, bedding plants are the largest contributor to the value of floriculture production. However, many of the popular bedding plant cultivars lack thermotolerance and may struggle to survive high temperatures during greenhouse production and in landscapes. High temperature is one of the primary abiotic stresses affecting plant growth and development in most parts of the world (Leong and Ong, 1983). Supraoptimal temperatures, those temperatures $10{ }^{\circ} \mathrm{C}$ to $15{ }^{\circ} \mathrm{C}$ above normal temperature $\left(\approx 25^{\circ} \mathrm{C}\right.$ for most plants), can increase respiration and therefore plants require greater $\mathrm{CO}_{2}$ fixation for sustained growth and survival (Thebud and Santarius, 1982). Karl et al. (1993) reported that the rise of the minimum global temperature has occurred at a rate three times that of the maximum temperature during the period 195190. Temperature increase can have a significant effect on plants, and air temperatures greater than $35^{\circ} \mathrm{C}$ decreased the Rubisco activity, thereby limiting photosynthesis in cotton (Gossypium hirsutum L. 'Coker 100A') and tobacco (Nicotiana rustica L. var. pumila Schrank) (Crafts-Brandner and Law, 2000). Inhibition of photosynthetic $\mathrm{CO}_{2}$ fixation under high temperature conditions has been documented in many plant species, including salvia (Salvia splendens). Under ambient conditions of $\mathrm{CO}_{2}$ and $\mathrm{O}_{2}$, photosynthesis and the export rates of

Received for publication 4 Feb. 2008. Accepted for publication 8 Apr. 2008. This paper is a portion of a dissertation submitted by S. Natarajan.

We thank PanAmerican Seed Company for providing seed for this project.

${ }^{1}$ Corresponding author. E-mail: jkuehny@1su.edu. assimilates in salvia declined as leaf temperature was raised from $25^{\circ} \mathrm{C}$ to $40{ }^{\circ} \mathrm{C}$ (Jiao and Grodzinski, 1996). Genotypes or lines within species differ in their ability to respond to heat stress. For example, when 12 open-pollinated families of white spruce (Picea glauca Moench) seedlings were exposed to high temperatures of $42{ }^{\circ} \mathrm{C}$ to $50{ }^{\circ} \mathrm{C}$ for $30 \mathrm{~min}$, the stability of photosystem II, as determined by chlorophyll fluorescence, decreased as temperature increased (Bigras, 2000). To overcome the effects of high temperature, plants also have evolved to adapt/acclimate and survive in stressful environmental situations (Senthil-Kumar et al., 2003). It is important to identify these heat-tolerant lines so that breeding programs can use these plants to improve the thermotolerance of new releases (Prasad et al., 1999). Many organisms, including plants, accumulate heat shock proteins (HSP) in response to high nonlethal temperatures to prevent denaturation of normal proteins (Vierling, 1991). Small heat shock proteins (sHSP) with molecular weights $\approx 15$ to $30 \mathrm{kD}$ are a class of HSP that predominate in plant species during heat stress (Waters et al., 1996). Some HSP are constitutively expressed (Perdue et al., 1998), whereas SHSP are rarely expressed in nonheat-stressed vegetative tissue, but can increase to over $1 \%$ of total protein upon heat stress (DeRocher et al., 1991; Waters et al., 1996). In pea (Pisum sativum L.), a class 1 cytosolic sHSP forms oligomers of 12 subunits with molecular weights between 200 to $240 \mathrm{kD}$ (Lee et al., 1995) that can bind denatured enzymes. This helps refolding of denatured proteins into normal functioning proteins and prevents aggregation (Jakob et al., 1993; Lee et al., 1995, 1997). Evidence from this and other studies suggest that in plants, sHSP play an important role in adaptation to high temperature stress (Harndahl et al., 1999). 
One of the primary plant adaptations to tolerate high temperature stress is commonly referred to as acquired thermotolerance. Several studies with a number of organisms, including plants, indicated that a brief exposure to sublethal high temperatures improved the ability of the organism to survive subsequent exposures to potentially lethal temperatures (Krebs and Loeschficke, 1994; O'Connell, 1994; Vierling, 1991). The capacity of plants to acclimate and survive under high temperature is a critical factor in heat tolerance. Some plants develop the ability to withstand severe temperatures when exposed to sublethal stress (induction stress), which is referred to as acquired thermotolerance (Senthil-Kumar et al., 2003). This adaptation or acclimatization to temperatures is considered one of the primary determinants of geographical distribution of plants (Mahan et al., 1997).

The phenomenon of thermotolerance has been found in herbaceous and woody plant species and is related to specific morphological traits. Senthil-Kumar et al. (2003) reported that the percentage of seedling survival and recovery growth of roots and shoots increased after a $2-\mathrm{h}$ induction treatment at $42{ }^{\circ} \mathrm{C}$ before challenging temperatures in seedlings of sunflower (Helianthus annuus L.). Acclimation of redbud (Cercis canadensis L.) seedlings for $21 \mathrm{~d}$ at $35{ }^{\circ} \mathrm{C}$ day $/ 25{ }^{\circ} \mathrm{C}$ night showed that ecotypes having thicker leaves had better plant growth and tolerated subsequent drought stress conditions (Griffin et al., 2004).

Many bedding plants are grown in situations where they encounter heat stress. Although there has been a great amount of information published on bedding plant production, relatively little information has been published on the effect of temperatures on bedding plants. Most of this information specifically addresses the effects of cold temperatures on bedding plant growth and development (Erwin et al., 2003). Few studies have reported on the effect of high temperature stress on bedding plants and tolerance mechanism or adaptation to high temperature stress (Deng and Harbaugh, 2006; Harbaugh and Deng, 2006, Warner and Erwin, 2002). Lasseigne et al. (1998) conducted a heat tolerance study on perennial salvias: woodland sage $(S . \times$ sylvestris L.), may night sage ( $S$. nemorosa L.), mexican bush sage (S. leucantha Cav.), texas sage ( $S$. gregii A. Gray.), and scarlet sage (S. splendens). Based on growth and development as effected by high temperatures of $20{ }^{\circ} \mathrm{C}$ to $40{ }^{\circ} \mathrm{C}$, it was reported that there was considerable variation in heat tolerance within this taxa of salvia. The severity of heat damage included symptoms such as severe chlorosis and necrosis of leaves, and growth distortions such as apical bud damage and poor shoot and root growth at high temperatures $\left(35^{\circ} \mathrm{C}\right.$ and $\left.40{ }^{\circ} \mathrm{C}\right)$. Some series of $S$. splendens released as heat-tolerant bedding plants perform poorly after transplant in the landscape. For example, the Sizzler series of salvia do not perform as well as other series when grown at higher than optimal temperatures (E. Leue, personal communication). Although extensive field evaluations are often conducted before the release of bedding plants, a better understanding of morphological, physiological, and anatomical adaptations of bedding plants to high temperatures may improve production practices and accommodate the selection of traits for breeding programs. Therefore, the objectives of this research were to study the affects of heat preconditioning and subsequent heat stress on whole plant growth, physiology and anatomy, and acclimation of the annual bedding plant salvia (S. splendens).

\section{Materials and Methods}

Plant growth. Two cultivars of S. splendens, 'Vista Red' and 'Sizzler Red', were selected for use in this study based on their perceived response to high temperatures as described by PanAmerican Seed Co. (E. Leue, personal communication). 'Vista Red' flowers later than 'Sizzler Red' allowing more time for establishment and has darker, green foliage. 'Vista Red' appears to grow and flower better at higher temperatures than 'Sizzler Red'; therefore, 'Sizzler Red' will be referred to as heat sensitive and 'Vista Red' as heat tolerant.

'Vista Red' and 'Sizzler Red' (PanAmerican Seed Co., West Chicago, IL) seeds were germinated in 10-cm-diameter (432 $\mathrm{cm}^{3}$ ) pots using a commercial substrate Jiffy Mix ${ }^{\circledR}$ (Jiffy Products, Shippegan, Canada). All plants were grown and each treatment was applied in one of three reach-in growth chambers (G series; Environmental Growth Chambers, Chagrin Falls, $\mathrm{OH})$. For the control plants and growth periods between preconditioning treatments, the day and night temperatures of $25^{\circ} \mathrm{C}$ day $/ 18^{\circ} \mathrm{C}$ night $\left( \pm 1.5^{\circ} \mathrm{C}\right)$ were maintained with a $14-\mathrm{h}$ photoperiod of $500 \mu \mathrm{mol} \cdot \mathrm{m}^{-2} \cdot \mathrm{s}^{-1}$ supplied by a combination of $115-\mathrm{W}$ very high output (VHO) fluorescent lamps (Sylvania, Danvers, MA) and 60-W incandescent lamps (Sylvania), and a relative humidity of $70 \%( \pm 5 \%)$. Plants were irrigated and fertilized on an as needed basis with $100 \mathrm{mg} \cdot \mathrm{L}^{-1} 15 \mathrm{~N}-2.2 \mathrm{P}-$ 12.4K (15-5-15 Cal Mg; Scotts-Sierra, Marysville, $\mathrm{OH}$ ) for the duration of the experiment. The media was kept moist at all times during the experiment.
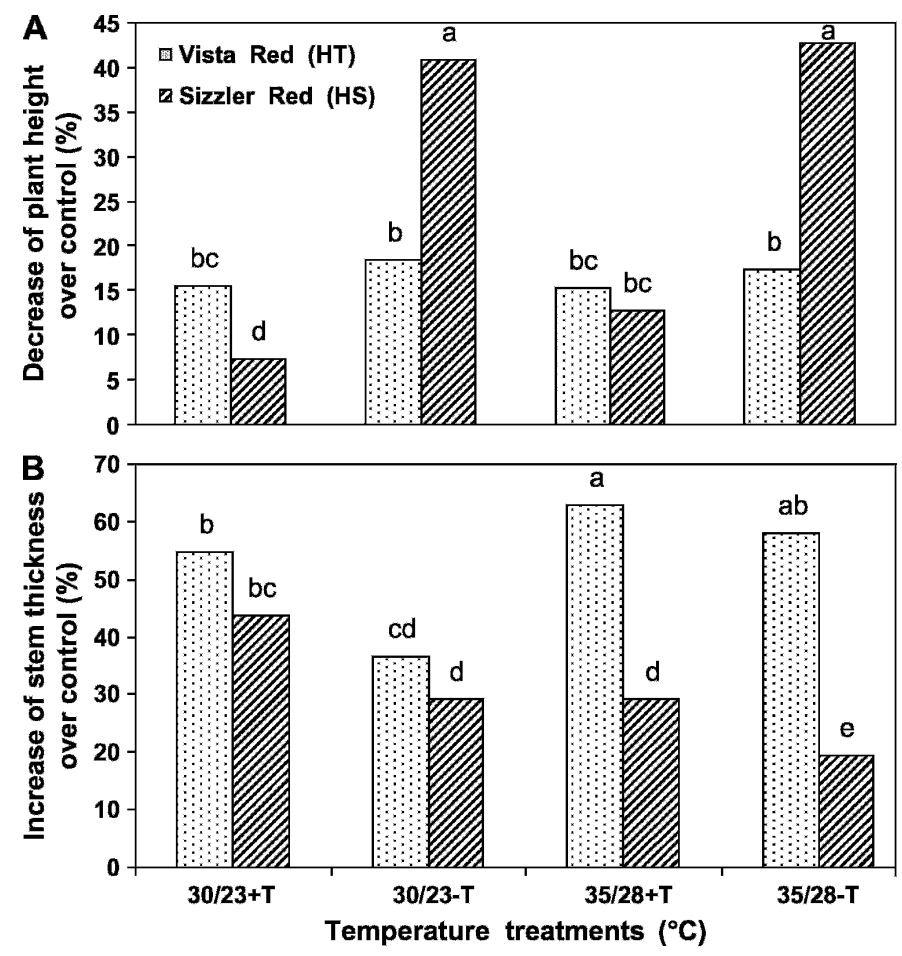

Fig. 1. Effect of heat preconditioning $\left(35^{\circ} \mathrm{C}\right.$ for $3 \mathrm{~h}$ every third day for 5 weeks) on the percentage of change in (A) plant height and (B) stem thickness in Salvia splendens 'Vista Red' and 'Sizzler Red' when exposed to two challenging temperatures, $30^{\circ} \mathrm{C}$ day $/ 23^{\circ} \mathrm{C}$ night or $35^{\circ} \mathrm{C}$ day $/ 28^{\circ} \mathrm{C}$ night; $+\mathrm{T}=$ heat precondition, $-\mathrm{T}=$ nonprecondition, $\mathrm{HT}=$ heat tolerant, $\mathrm{HS}=$ heat sensitive. Columns with different letters are significantly different by Tukey's test at $P<0.05$. 
HEAT PRECONDITIONING AND TEMPERATURE TREATMENT. TWOweek-old seedlings were subjected to short-duration heat preconditioning at $35{ }^{\circ} \mathrm{C}$ for $3 \mathrm{~h}$ every third day for 3 weeks. This treatment was determined to be the most effective for heat preconditioning of salvia (Natarajan and Kuehny, 2005). The 5 -week-old heat-preconditioned and nonpreconditioned plants were then transferred to two high-temperature conditions (challenging temperatures) of $30{ }^{\circ} \mathrm{C}$ day $/ 23{ }^{\circ} \mathrm{C}$ night and $35{ }^{\circ} \mathrm{C}$ day $/ 28{ }^{\circ} \mathrm{C}$ night for three weeks. Preliminary studies indicated that temperatures of $30{ }^{\circ} \mathrm{C}$ to $35{ }^{\circ} \mathrm{C}$ deleteriously affected growth of salvia and thus were considered challenging temperatures (Natarajan, 2005). A group of control plants was grown at $25{ }^{\circ} \mathrm{C}$ day $/ 18{ }^{\circ} \mathrm{C}$ night for the 8 -week duration of the experiment. The control temperature was based on $18{ }^{\circ} \mathrm{C}$ to $25{ }^{\circ} \mathrm{C}$, considered the optimum range for greenhouse production of salvia (Nau, 1998). Temperatures of $28{ }^{\circ} \mathrm{C}$ to $35^{\circ} \mathrm{C}$ commonly occur in transitional and warm climatic regions during mid-summer. Tissue sampling and all plant measurements were taken at the end of the 8-week experiment.

Plant growth. Plant growth in terms of shoot lengths and stem thickness were measured at the end of 8 weeks in heatpreconditioned and nonpreconditioned plants grown at two challenging temperatures. Plant height was measured from the soil line to the apical meristem, and stem thickness was measured at the third internode from the apex. Shoots and roots were harvested and placed in a forced air dryer (model 1660; VWR, West Chester, PA) at $75{ }^{\circ} \mathrm{C}$ for $48 \mathrm{~h}$ and dry weights were recorded.
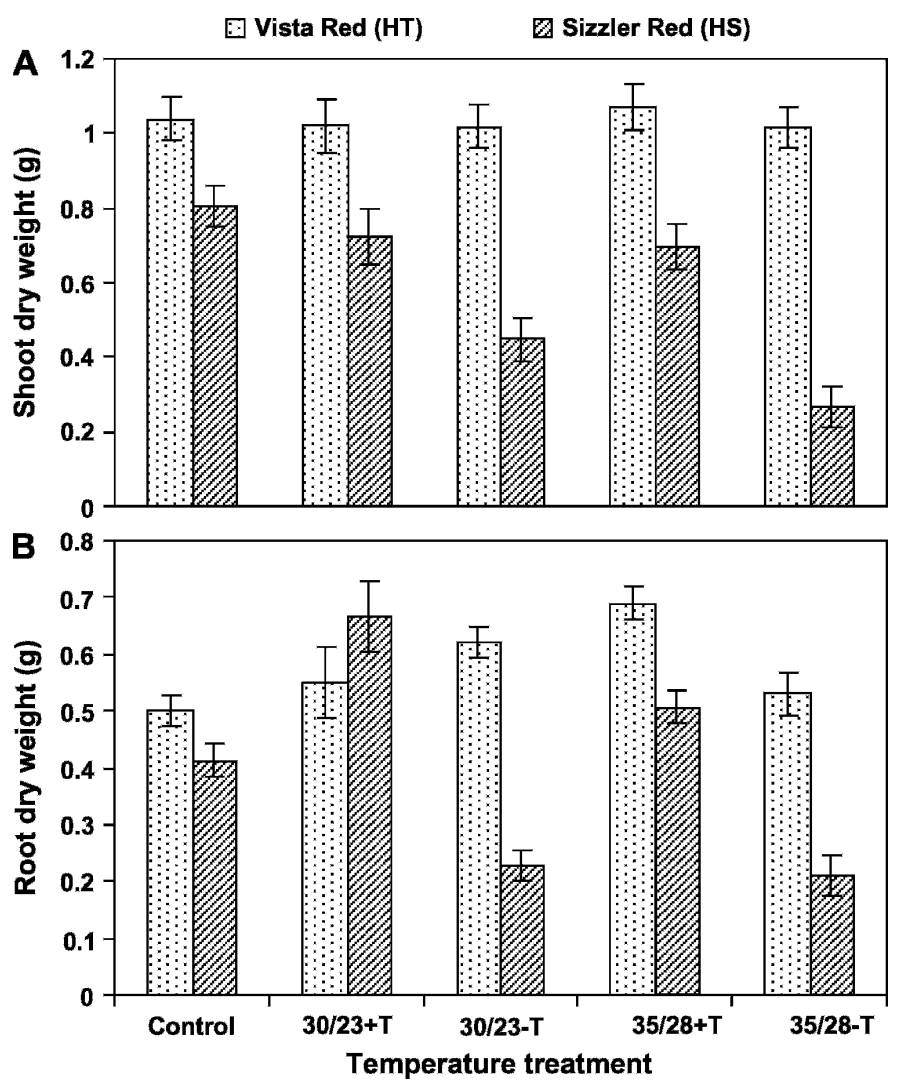

Fig. 2. Effect of heat preconditioning $\left(35^{\circ} \mathrm{C}\right.$ for $3 \mathrm{~h}$ every third day for 3 weeks $)$ on (A) shoot and (B) root dry weights in Salvia splendens 'Vista Red' and 'Sizzler Red' when exposed to two challenging temperatures, $30^{\circ} \mathrm{C}$ day $/ 23{ }^{\circ} \mathrm{C}$ night or $35^{\circ} \mathrm{C}$ day $/ 28^{\circ} \mathrm{C}$ night; $+\mathrm{T}=$ heat precondition, $-\mathrm{T}=$ nonprecondition, $\mathrm{HT}=$ heat tolerant, $\mathrm{HS}=$ heat sensitive. Error bars represent SE $(n=6)$.
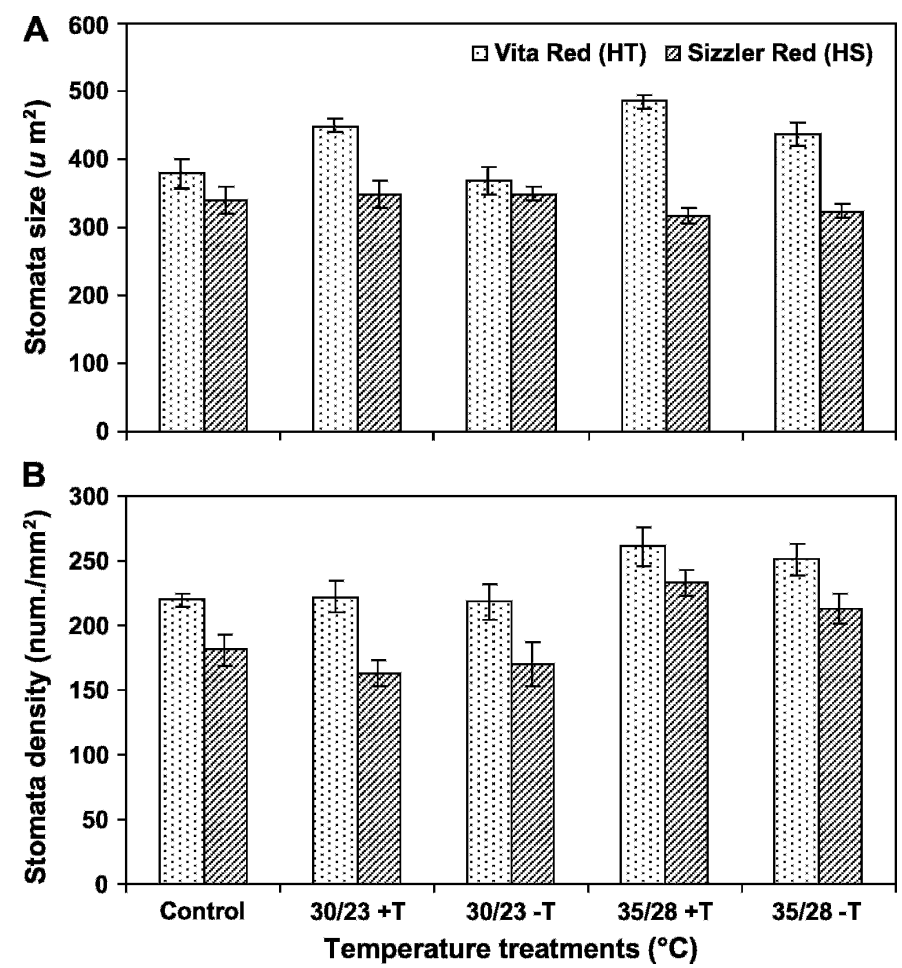

Fig. 3. Effect of heat preconditioning $\left(35^{\circ} \mathrm{C}\right.$ for $3 \mathrm{~h}$ every third day for 3 weeks $)$ on (A) stomata size and (B) stomata density in Salvia splendens 'Vista Red' and 'Sizzler Red' when exposed to two challenging temperatures, $30^{\circ} \mathrm{C}$ day/ $23{ }^{\circ} \mathrm{C}$ night or $35{ }^{\circ} \mathrm{C}$ day $/ 28{ }^{\circ} \mathrm{C}$ night; $+\mathrm{T}=$ heat precondition, $-\mathrm{T}=$ nonprecondition, $\mathrm{HT}=$ heat tolerant, $\mathrm{HS}=$ heat sensitive. Error bars represent SE $(\mathrm{n}=6)$.

Photosynthesis, stomatal conductance, and TRANSPIRATION. A portable photosynthesis system (CIRAS-1; PP systems, Amesbury, MA) was used to measure net photosynthesis $\left(\mathrm{P}_{\mathrm{n}}\right)$, stomatal conductance $\left(\mathrm{g}_{\mathrm{S}}\right)$, and transpiration (T). Measurements were recorded under a photosynthetic photon flux of $500 \mu \mathrm{mol} \cdot \mathrm{m}^{-2} \cdot \mathrm{s}^{-1}$ on recently matured leaves of 8-week-old plants; two measurements were recorded per plant on separate leaves.

STOMATA SIZE, STOMATAL NUMBER, AND LEAF THICKNESS. Two recently matured leaf samples from each 8-week-old plant were collected during the middle of the day and were immediately processed to obtain scanning electron micrograph (SEM) images. Leaves prepared for SEM were mounted on stubs, coated with 25-nm gold palladium using a Hummer II Sputter Coater (Thin Film Division, Anatech, Denver, NC), and examined on a scanning electron microscope (Cambridge S-260; Carl Zeiss SMT, Thornwood, NY). Images of cross section, adaxial, and abaxial surfaces were magnified to fixed resolution (300× for stomata and $200 \times$ for leaf cross section). Leaves of salvia are amphistomatous. Because stomata on adaxial surfaces are more sensitive to environment variables (Aston, 1978), stomata number and size on adaxial surfaces were chosen for comparison. SEM images were used to measure the size of stomata, stomatal frequency, and leaf thickness using ImageJ imaging software (version 1.33; National Institutes of Health, Bethesda, MD). Measurements were made by using a standard $200-\mu \mathrm{M}$ reference bar on each of the SEM images.

Tissue PREPARATION, SDS PAGE, AND WESTERn BLOTTING. The same two recently matured leaves that were used for 


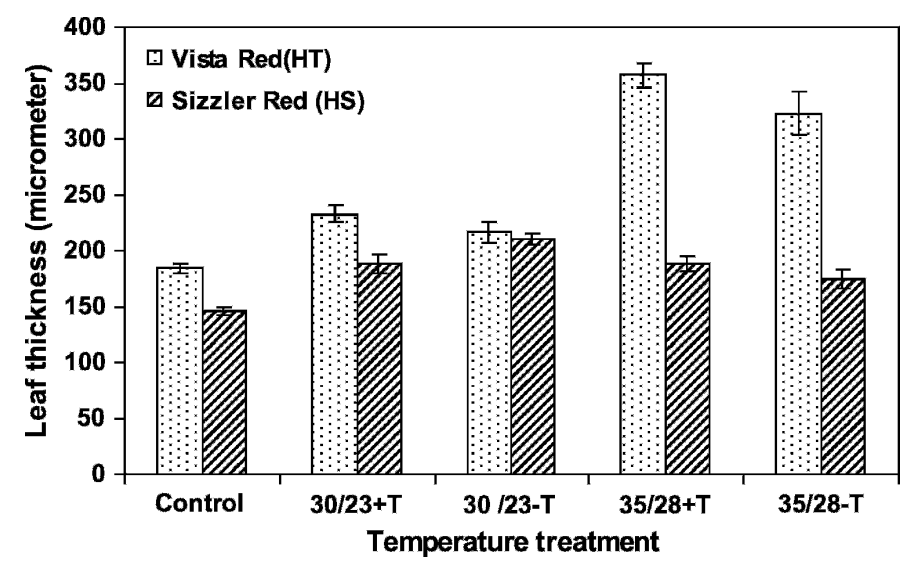

Fig. 4. Effect of heat preconditioning $\left(35^{\circ} \mathrm{C}\right.$ for $3 \mathrm{~h}$ every third day for 3 weeks $)$ on leaf thickness in Salvia splendens 'Vista Red' and 'Sizzler Red' when exposed to two challenging temperatures, $30^{\circ} \mathrm{C}$ day $/ 23^{\circ} \mathrm{C}$ night or $35^{\circ} \mathrm{C}$ day/ $28{ }^{\circ} \mathrm{C}$ night; $+\mathrm{T}=$ heat precondition, $-\mathrm{T}=$ nonprecondition, $\mathrm{HT}=$ heat tolerant, $\mathrm{HS}=$ heat sensitive. Error bars represent $\mathrm{SE}(\mathrm{n}=6)$.

photosynthesis measurements were harvested for quantifying sHSP $(\approx 27 \mathrm{kD})$ expression and were immediately frozen. Frozen tissue samples were ground to fine powder using liquid nitrogen. Leaf protein was extracted from $0.1 \mathrm{~g}$ of tissue using the protocol from Downs and Heckathorn (1998) in buffer containing $100 \mathrm{mmol} \cdot \mathrm{L}^{-1}$ Tris- $\mathrm{HCl}(\mathrm{pH} 8.0)$, $1 \%$ sodium dodecyl sulfate (SDS; w/v), $1 \%$ dithiothreitol (w/v), $1 \mathrm{mmol}$ $\mathrm{L}^{-1}$ phenyl methyl sulfonylfluoride, $5 \mu \mathrm{mol} \cdot \mathrm{L}^{-1}$ leupeptin, $5 \mathrm{mmol} \cdot \mathrm{L}^{-1} \varepsilon$-amino caproic acid, $1 \%$ ascorbate $(\mathrm{w} / \mathrm{v})$, and $3 \mathrm{mmol} \cdot \mathrm{L}^{-1} \mathrm{Na}_{2}$ EDTA (Sigma, St. Louis). Three percent (w/v) polyvinylpyrrolidone and $30 \mathrm{mmol} \mathrm{L}^{-1}$ sodium tetraborate were used to remove phenolics. Samples were boiled for $3 \mathrm{~min}$ and
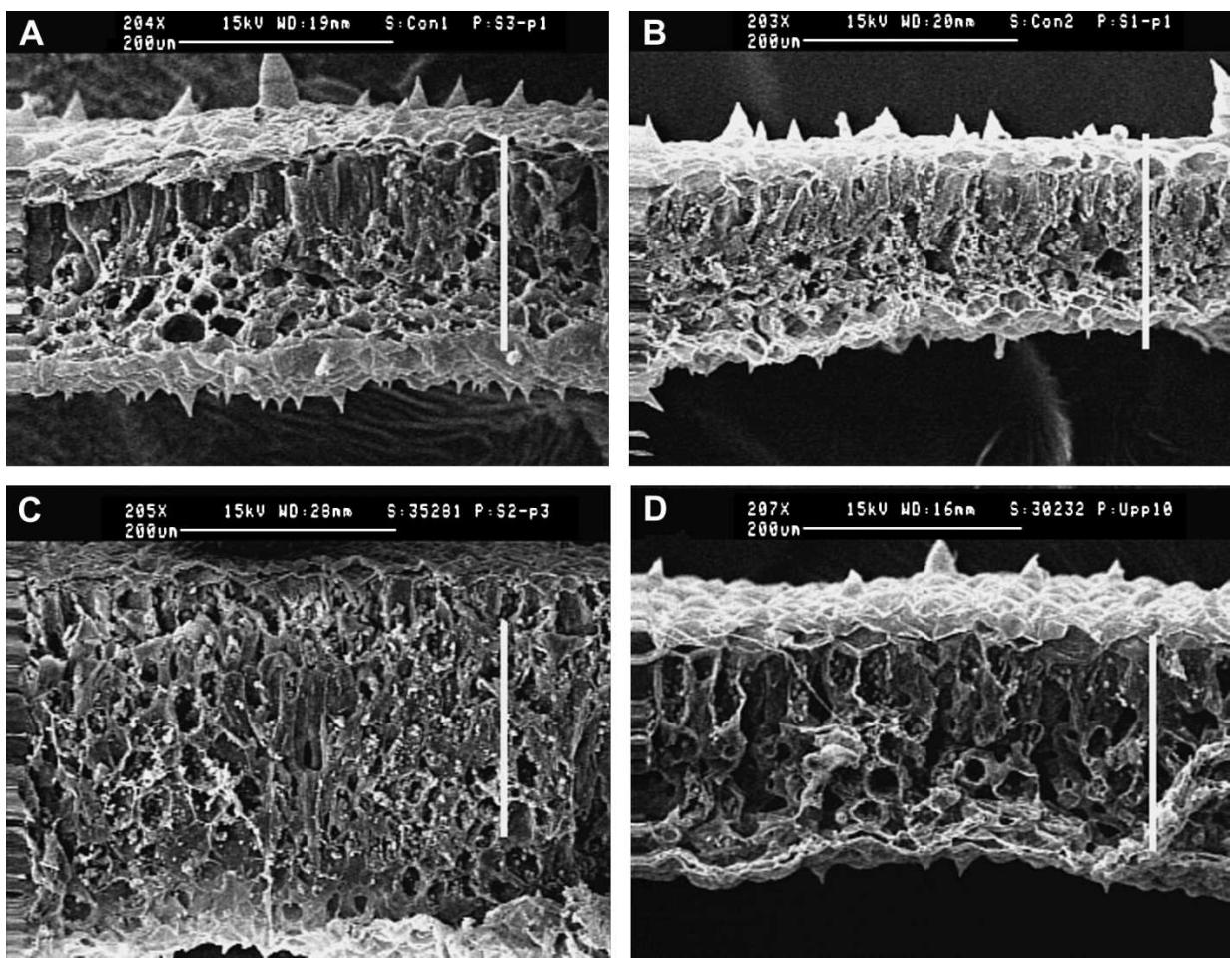

Fig. 5. Leaf cross section SEM images at 200× magnification of Salvia splendens (A) 'Vista Red' control, (B) 'Sizzler Red' control, (C) 'Vista Red' $35^{\circ} \mathrm{C}$ day $/ 28^{\circ} \mathrm{C}$ night $+\mathrm{T}$, and (D) 'Sizzler Red' $35^{\circ} \mathrm{C}$ day $/ 28^{\circ} \mathrm{C}$ night $+\mathrm{T}$ $\left(+\mathrm{T}=\right.$ heat preconditioning at $35^{\circ} \mathrm{C}$ for $3 \mathrm{~h}$ every third day for 3 weeks). Vertical line indicates $200 \mu \mathrm{m}$ scale. were then centrifuged at $14,000 g_{\mathrm{n}}$ for $6 \mathrm{~min}$. The supernatant was collected and stored at $-80^{\circ} \mathrm{C}$.

Total protein content from leaf extract was determined according to Bradford assay (Bradford, 1976), bovine serum albumin was used as a standard. The soluble proteins were fractionated on $15 \%$ one dimensional SDS-PAGE gels as described previously by Laemmli (1970) and electro transferred to a $0.45-\mu \mathrm{m}$ nitrocellulose membrane (Towbin et al., 1979). After protein transfer, the nitrocellulose membranes were blocked in $1 \%(\mathrm{w} / \mathrm{v})$ bovine serum albumin and incubated with chloroplast sHSP antibody and appropriate secondary antibodies. Constitutive expression of these sHSP was assessed in plants maintained at control conditions. Inducible expression of these proteins was assessed after heat preconditioning and subsequent growth at two challenging temperatures. Molecular mass standards were included on all gels (Precision Plus Protein standards; Bio-Rad, Hercules, CA). The relative amounts of protein-antibody complexes were estimated using a desktop scanner (Scanjet 3300C; Hewlett Packard, Palo Alto, CA) and ImageJ imaging software (version 1.33).

MARKeTABLe QuALity. Overall marketable quality was visually assessed weekly after heat stress treatments were initiated based on leaf color, terminal bud necrosis, and flowering on a 1 to 10 scale, according to the following criteria: 9 or $10=$ excellent plants with healthy green leaves and good inflorescence, $8=$ green healthy foliage with moderate flowers, $7=$ plants with poor inflorescence, 5 or $6=$ necrotic leaves and poor flower set, $4=$ terminal bud damage, 2 or $3=$ dried leaves, and $1=$ deceased.

Statistical analysis. There were six experimental units per temperature treatment following a completely randomized design within the growth chamber. ProcMix and LSD adjusted by Tukey's method were performed using SAS (SAS Institute, Cary, $\mathrm{NC)}$ to evaluate the significant difference between parameters measured. Correlation coefficients were obtained to analyze the association between marketable quality and growth parameters.

\section{Results}

The influence of short duration heat preconditioning temperature on growth and development was evident from the alteration in morphological and physiological characteristics of 'Sizzler Red' and 'Vista Red'. Heat preconditioning and prolonged heat stress altered overall plant growth by reducing internode length and leaf size, and by altering leaf orientation compared with plants grown under control conditions (data not shown). The percentage of reduction of plant height in nonpreconditioned 'Sizzler Red' was significantly greater than 'Vista Red' grown at both challenging temperatures and preconditioned 'Sizzler Red' plants 
(Fig. 1A). Plant height for 'Vista Red', unlike 'Sizzler Red', was unaffected by preconditioning. Both cultivars grown at challenging temperatures with and without heat preconditioning, resulted in increased stem thickness, and 'Vista Red' had a greater percentage of increase in stem thickness at the $35{ }^{\circ} \mathrm{C}$ day $/ 28$ night ${ }^{\circ} \mathrm{C}$ challenging temperature when compared with 'Sizzler Red' at both challenging temperatures (Fig. 1B). Heat preconditioning resulted in a greater increase in stem thickness at $30{ }^{\circ} \mathrm{C}$ for 'Vista Red' than nonpreconditioned, at $\approx 10 \%$, but for 'Sizzler Red', this increase was $\approx 4 \%$ and $10 \%$ at $30{ }^{\circ} \mathrm{C}$ and $35^{\circ} \mathrm{C}$, respectively.

Plant dry matter accumulation varied by cultivar and among treatments. Results showed that 'Vista Red' is more efficient in dry matter accumulation when compared with 'Sizzler Red' (Fig. 2, A and B). Heat-preconditioned 'Sizzler Red' plants maintained greater shoot and root growth at $30{ }^{\circ} \mathrm{C}$ or $35{ }^{\circ} \mathrm{C}$ challenging temperatures compared with nonpreconditioned plants. 'Vista Red' showed no significant changes in shoot dry weights over the control; however, root growth of preconditioned plants was greater at $35^{\circ} \mathrm{C}$ (Fig. 2B).

Comparison of the two cultivars showed significant differences in leaf anatomical characteristics under control and challenging temperature treatments. In general, 'Vista Red' had higher stomatal frequency on the adaxial surface and larger stomatal apparatus than 'Sizzler Red' (Fig. 3, A and B). Temperature treatments altered the stomata size in both the cultivars. Control and nonpreconditioned plants at $30{ }^{\circ} \mathrm{C}$ day/ $23{ }^{\circ} \mathrm{C}$ night, showed no difference in size of the stomata in either of the cultivars. Heat-preconditioned 'Vista Red' had a greater stomata size than the control, nonpreconditioned 'Vista Red' at $30^{\circ} \mathrm{C}$ day $/ 23^{\circ} \mathrm{C}$ night and 'Sizzler Red' at all temperature treatments. There were no differences in stomata size of preconditioned and nonpreconditioned 'Sizzler Red' exposed to $30{ }^{\circ} \mathrm{C}$ day $/ 23{ }^{\circ} \mathrm{C}$ night or $35^{\circ} \mathrm{C}$ day $/ 28^{\circ} \mathrm{C}$ night. However, those plants exposed to $30{ }^{\circ} \mathrm{C}$ day $/ 23{ }^{\circ} \mathrm{C}$ night resulted in a similar stomata size as the control. Heat preconditioning had no effect on stomata density of either cultivars. In both the cultivars, stomata density was significantly greater at higher challenging temperature $35{ }^{\circ} \mathrm{C}$ day/28 ${ }^{\circ} \mathrm{C}$ night with and without preconditioning compared with rest of the treatments. Between the two cultivars, 'Vista Red' had a higher stomata density for all the treatments.

'Vista Red' with and without heat precondition treatment, then challenged at $35{ }^{\circ} \mathrm{C}$ day $/ 28{ }^{\circ} \mathrm{C}$ night and preconditioned plants subsequently challenged at $30{ }^{\circ} \mathrm{C}$ day $/ 23{ }^{\circ} \mathrm{C}$ night resulted in significant increase in leaf thickness over control and 'Sizzler Red' (Fig. 4). Increase in leaf thickness was greater under the $35^{\circ} \mathrm{C}$ challenging temperature when compared with the $30{ }^{\circ} \mathrm{C}$ challenging temperature for 'Vista Red'. 'Sizzler Red' leaf thickness increased at the $30{ }^{\circ} \mathrm{C}$ challenging temperature over the control plants; preconditioned plants had greater leaf thickness at the $35{ }^{\circ} \mathrm{C}$ challenging temperature over nonpreconditioned plants. SEM images provide a visual representation of increase in leaf thickness over control when the plants were preconditioned for 'Vista Red' and 'Sizzler Red' (Fig. 5).

Regardless of treatment temperature, $g_{\mathrm{S}}$ and $\mathrm{P}_{n}$ were greater for 'Vista Red' and 'Sizzler Red' compared with the control (Fig. 6, A-C). For 'Sizzler Red', preconditioned and nonpreconditioned plants at $35{ }^{\circ} \mathrm{C}$ day $/ 28{ }^{\circ} \mathrm{C}$ night had a higher transpiration rate compared with control and plants at $30^{\circ} \mathrm{C}$ day $/ 23{ }^{\circ} \mathrm{C}$ night. Net photosynthesis was greater at $35^{\circ} \mathrm{C}$ day/
$28{ }^{\circ} \mathrm{C}$ night in preconditioned 'Sizzler Red' compared with other treatments. Comparing the cultivars, 'Vista Red', after heat preconditioning, had greater $\mathrm{P}_{n}$ at both the challenging temperatures compared with 'Sizzler Red', and both cultivars had greater transpiration at $35^{\circ} \mathrm{C}$ day $/ 28^{\circ} \mathrm{C}$ night. Throughout the experiment, $g_{\mathrm{S}}$ at both challenging temperatures was greater for 'Vista Red' and 'Sizzler Red' with and without preconditioning when compared with control. However, comparing the two cultivars, preconditioning had no affect on $g_{\mathrm{S}}$.

'Vista Red' and 'Sizzler Red' control plants, as well as plants exposed to two challenging temperatures with and without preconditioning, resulted in synthesis of sHSP of $\approx 27 \mathrm{kD}$ (Fig. 7, A-C). However, the intensity of bands increased under challenging temperatures. 'Vista Red' synthesized a greater amount of sHSP than 'Sizzler Red' for all treatments. Preconditioning decreased sHSP production in 'Sizzler Red' at $30{ }^{\circ} \mathrm{C}$ day $/ 23^{\circ} \mathrm{C}$ night and 'Vista Red' at $35^{\circ} \mathrm{C}$ day $/ 28^{\circ} \mathrm{C}$ night.

Nonpreconditioned 'Sizzler Red' plants showed severe marginal burning of leaves, apical bud damage, and poor
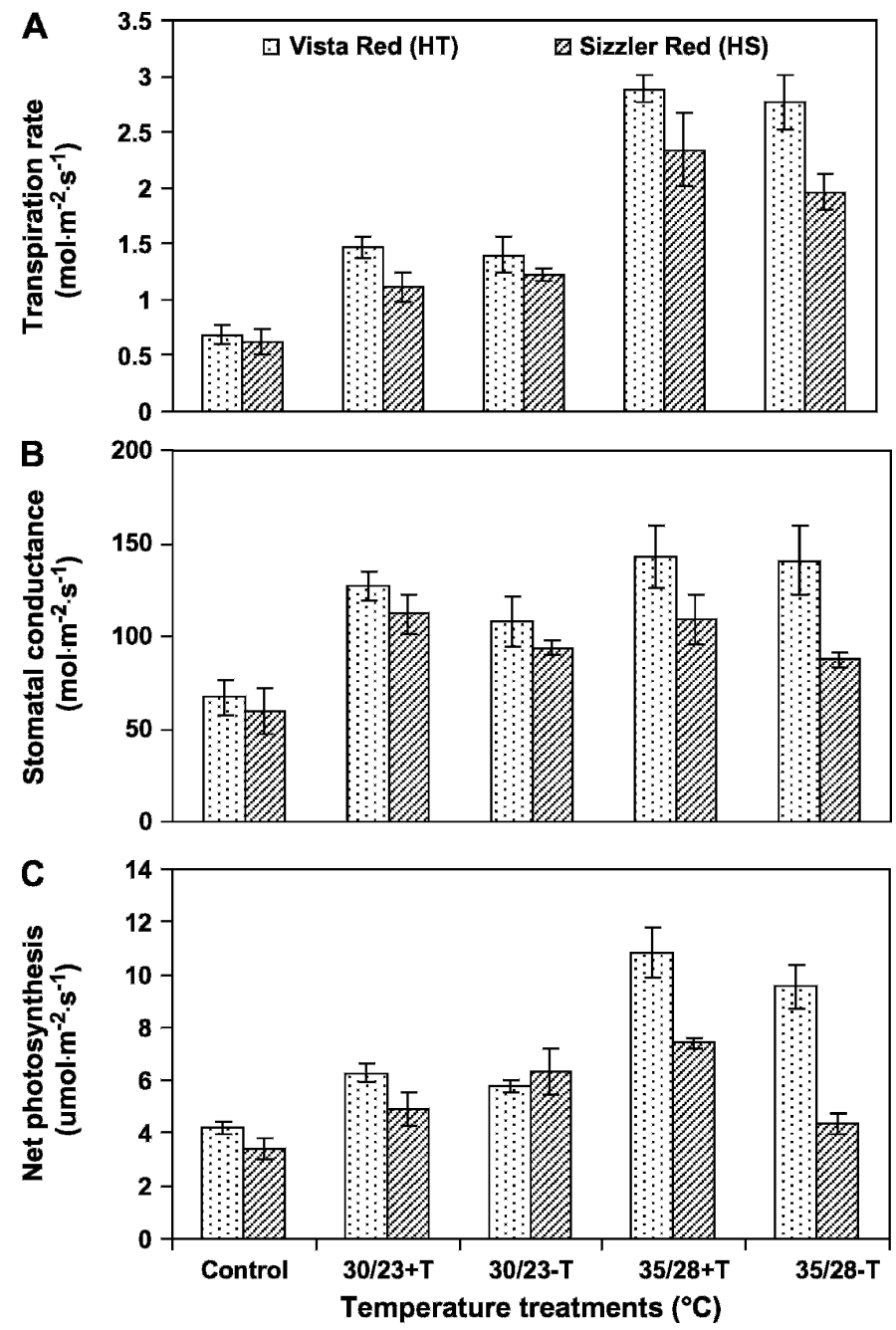

Fig. 6. Effect of heat preconditioning $\left(35^{\circ} \mathrm{C}\right.$ for $3 \mathrm{~h}$ every third day for 3 weeks $)$ on (A) transpiration, (B) $g_{\mathrm{S}}$, and (C) net photosynthesis in Salvia splendens 'Vista Red' and 'Sizzler Red' when exposed to two challenging temperatures, $30{ }^{\circ} \mathrm{C}$ day $/ 23^{\circ} \mathrm{C}$ night or $35^{\circ} \mathrm{C}$ day $/ 28^{\circ} \mathrm{C}$ night; $+\mathrm{T}=$ heat precondition, $-\mathrm{T}=$ nonprecondition, $\mathrm{HT}=$ heat tolerant, $\mathrm{HS}=$ heat sensitive. Error bars represent $\operatorname{SE}(\mathrm{n}=6)$. 
flowering compared with the control and 'Vista Red' plants. The marketable quality of 'Vista Red' remained unchanged regardless of treatment (Table 1). The percentage of reduction in marketable quality of nonpreconditioned 'Sizzler Red' at the $30{ }^{\circ} \mathrm{C}$ or $35^{\circ} \mathrm{C}$ challenging temperatures was $25 \%$ and $58.9 \%$, respectively, compared with control. However, preconditioning enhanced the marketable quality of 'Sizzler Red' compared with nonpreconditioned plants. Correlation coefficients for association of marketable quality with plant height, stem thickness, and shoot and root dry weights showed a negative correlation with plant height (Table 2). However, a positive correlation was indicated for stem thickness, and root and shoot dry weight.

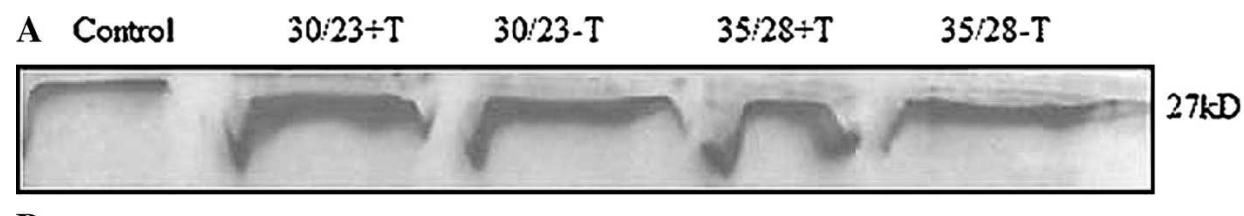

B
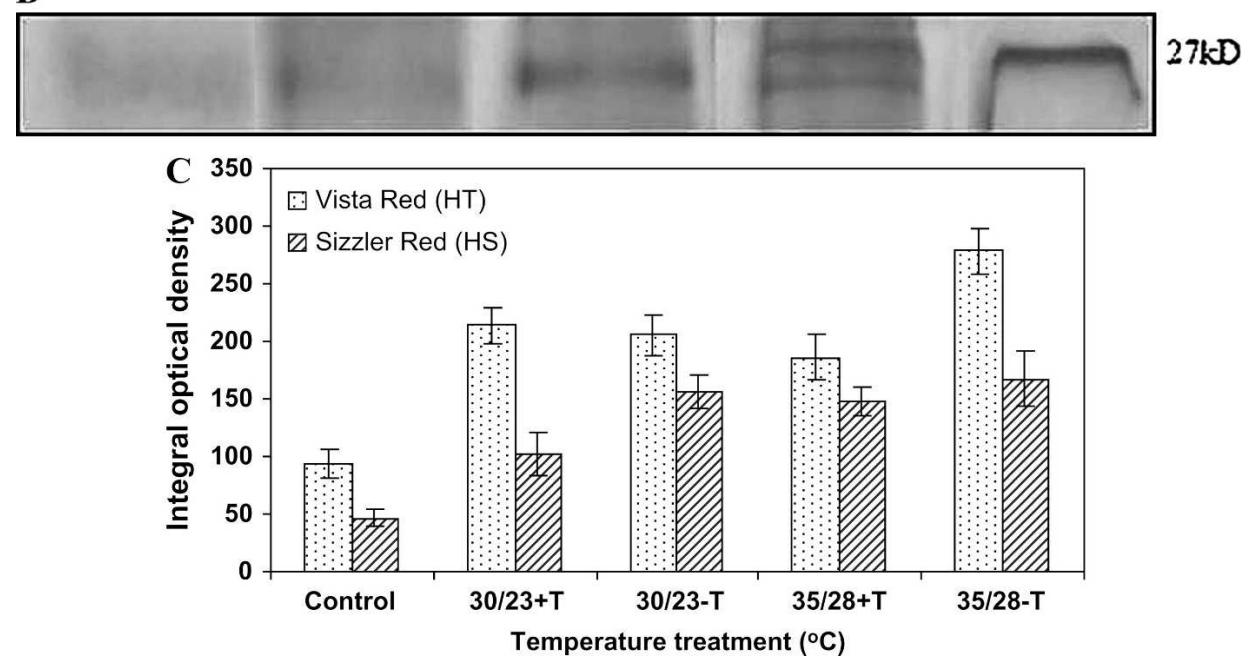

Fig. 7. Effect of heat preconditioning $\left(35^{\circ} \mathrm{C}\right.$ for $3 \mathrm{~h}$ every third day for 3 weeks) and exposure to two challenging temperatures, $30{ }^{\circ} \mathrm{C}$ day $/ 23{ }^{\circ} \mathrm{C}$ night or $35^{\circ} \mathrm{C}$ day/28 ${ }^{\circ} \mathrm{C}$ night on synthesis of sHSP27 in Salvia splendens: (A) 'Vista Red' (heat tolerant) or (B) 'Sizzler Red' (heat sensitive). (C) Integral optical density values measured using ImageJ imaging software (version 1.33; National Institutes of Health, Bethesda, MD). Error bars represent SE $(n=6) ;+T=$ heat precondition, $-\mathrm{T}=$ nonprecondition, $\mathrm{HT}=$ heat tolerant, $\mathrm{HS}=$ heat sensitive.

Table 1. Effect of heat preconditioning $\left(35^{\circ} \mathrm{C}\right.$ for $3 \mathrm{~h}$ every third day for 3 weeks) on overall marketable quality of Salvia splendens 'Vista Red' and 'Sizzler Red' when exposed to two challenging temperatures $30{ }^{\circ} \mathrm{C}$ day $/ 23{ }^{\circ} \mathrm{C}$ night or $35^{\circ} \mathrm{C}$ day $/ 28^{\circ} \mathrm{C}$ night.

\begin{tabular}{|c|c|c|c|c|c|}
\hline \multirow[b]{3}{*}{ Cultivar $^{\mathrm{z}}$} & \multicolumn{5}{|c|}{ Temperature treatments $\left({ }^{\circ} \mathrm{C}\right)^{\mathrm{y}}$} \\
\hline & Control & $30 / 23+\mathrm{T}$ & $30 / 23-\mathrm{T}$ & $35 / 28+\mathrm{T}$ & $35 / 28-\mathrm{T}$ \\
\hline & \multicolumn{5}{|c|}{ Marketable quality [1-10 scale (\% decrease vs. control)] } \\
\hline 'Vista Red' (HT) & $9.5 \mathrm{a}^{\mathrm{x}}$ & $9.3(-1.8) \mathrm{a}$ & $8.8(-7.0) \mathrm{a}$ & $8.5(-10.5) a b$ & $8.30(-12.2) \mathrm{abc}$ \\
\hline 'Sizzler Red' (HS) & $9.3 \mathrm{a}$ & $8.2(-12.5) \mathrm{ab}$ & $7.0(-25) \mathrm{cd}$ & $8.1(-12.5) \mathrm{ab}$ & $3.83(-59) \mathrm{d}$ \\
\hline
\end{tabular}

${ }^{\mathrm{z}} \mathrm{HT}=$ heat tolerant, HS $=$ heat sensitive.

${ }^{\mathrm{y}}+\mathrm{T}=$ heat precondition, $-\mathrm{T}=$ nonprecondition.

${ }^{\mathrm{x}}$ Values with different letters are significantly different at $P<0.05$.

Table 2. Correlation coefficients for association of marketable quality of Salvia splendens with morphological traits plant height, stem thickness, and shoot and root dry weights.

\begin{tabular}{lcccc}
\hline & Plant height & Stem thickness & Shoot dry wt & Root dry wt \\
\hline Marketable quality & -0.59 & 0.3 & 0.7 & 0.5 \\
$(P$ value $)$ & $(<0.001)$ & $(0.0206)$ & $(<0.001)$ & $(<0.001)$ \\
\hline
\end{tabular}

\section{Discussion}

In this study, short duration heat preconditioning followed by growing salvia in challenging temperatures revealed cultivar differences in genetic or inherited thermotolerance and acquired thermotolerance. Acquired thermotolerance is defined atures (Senthil-Kumar et al., 2003). In salvia, acquired thern tolerance was observed in morphological traits (stem thickness, root and shoot growth), physiological (photosynthesis), and atomical traits (stomata size) studied.

cultivars used in this study were different in their appearance and growth habit according to the plant breeder (E. Leue, personal communication). These differences were enhanced when grown under challenging temperatures and heat preconditioning for both cultivars. In general, 'Vista Red' had more heattolerant morphological traits such as shorter plants, thicker stems, thicker and darker green leaves, and better shoot and root growth, and were more heat tolerant than 'Sizzler Red', which lacked these traits. However, 'Sizzler Red' developed some of these traits after preconditioning and acclimated to challenging temperatures. 'Vista Red' maintained and enhanced existing or inherited morphological traits and tolerated challenging temperatures. Similar acquired thermotolerance has been found in woody and herbaceous plant species. Griffin et al. (2004) reported that of acclimation, redbud (Cercis canadensis L.) seedlings at $35^{\circ} \mathrm{C}$ day $/ 25$ ${ }^{\circ} \mathrm{C}$ night showed an increase in leaf thickness and plant growth. Seedling survival and recovery growth increased after acclimation treatment in seedlings of $H$. annuus (Senthil-Kumar et al., 2003).

Results with respect to leaf thickness in the present study showed that both cultivars developed thicker leaves under high temperature conditions; however, 'Vista Red' was thicker than 'Sizzler Red'. Increased leaf thickness irrespective of cultivar could be attributed to increased cuticular thickening, mesophyll layer, and spongy parenchyma in both cultivars at challenging temperatures (Fig. 5). Leaf orientation became more vertical to the stem in both cultivars after heat preconditioning. Gratani and Ghia (2002) found that 
the adaptive strategy of strawberry tree (Arbutus unedo L.) may be to increase leaf area and leaf lamina thickness, thereby increasing the capacity of light interception and gas exchange, respectively, with a steeper leaf inclination. Combined, these may be a prevention mechanism against photoinhibition.

Harbaugh and Scott (2001) reported that semidwarf cultivars of lisianthus (Eustoma grandiflorum Salisb.), Florida Pink and Florida Blue, released as heat-tolerant cultivars, were more suitable as bedding plants in landscapes than cultivars with longer internodes. In a study conducted on cultivars of cowpea [Vigna unguiculata (L.) Walp.], Ismail et al. (2000) reported that heat-susceptible lines of cowpea were taller due to their longer internodes. In our study, 'Sizzler Red' plants had longer internodes and were more susceptible to high temperatures than 'Vista Red'. Heat preconditioning resulted in a decrease in internode length in 'Sizzler Red' and 'Vista Red'. This induced plant hardening and dwarfness may have improved the heat tolerance levels in salvia cultivars. Several studies reported similar results in other crops (Krebs and Loeschficke, 1994; O’Connell, 1994; Vierling, 1991).

Plant quality and survival capacity under high temperatures depend upon root and shoot growth (Jiang and Huang, 2000, 2001). Various turfgrass studies reported that a deep and extensive root system contribute positively to the increased water uptake under water or heat stress conditions that increased plant quality and appearance (Huang and Fry, 1998; Jiang and Huang, 2000, 2001). Root growth improved with heat preconditioning for both cultivars of salvia at the $35^{\circ} \mathrm{C}$ challenging temperature (Fig. 2B). However, 'Vista Red' generally had greater root growth compared with 'Sizzler Red'. An extensive root system facilitates increased transpirational cooling by improved water movement, resulting in reduced leaf temperature and thus heat tolerance (Engelke, 1985; Kolb and Robberecht, 1996; Xu and Huang, 2000). Bonos and Murphy (1999) reported that root growth of heat-tolerant kentucky bluegrass (Poa pratensis L.) was significantly greater than heatsensitive cultivars at various soil depths. As challenging temperatures increased for almost all treatments of this experiment, transpiration rate and $g_{S}$ increased for 'Vista Red' and 'Sizzler Red' (Fig. 6, A and B). 'Sizzler Red' maintained lower transpiration rates for most temperature treatments, which could have caused the foliar necrosis of newly emerging as well as fully developed leaves previously mentioned. The lower amount of heat stress damage as occurred with 'Vista Red' could be due to their thicker leaves, particularly the thicker mesophyll layer (Fig. 5C). Species that are adapted to sunny and dry environments usually have small, thick leaves (Givnish, 1987; Turner, 1994a, 1994b). These traits permit the greatest carbon gain per unit transpirational loss (Givnish, 1987). The same adaptive characteristics were prevalent in 'Vista Red' and heat-preconditioned 'Sizzler Red'.

Another unique molecular characteristic of plants and other thermophillic bacteria growing under high temperature conditions is greater expression of HSP synthesis (Knight and Ackerly 2003; Roy and Nakamoto, 1998). Increased synthesis of sHSP coincided with increased challenging temperatures of 'Vista Red' and 'Sizzler Red', irrespective of preconditioning. However, preconditioning decreased sHSP production for 'Vista Red' at $35^{\circ} \mathrm{C}$ day $/ 28^{\circ} \mathrm{C}$ night and 'Sizzler Red' at $30^{\circ} \mathrm{C}$ day $/ 28{ }^{\circ} \mathrm{C}$ night. Thus, acquired thermotolerance does not appear to include increased production of sHSP for these series of salvia as with wild-type tomato (Solanum lycopersicum L.) that overexpressed HSP synthesis and survived under high temperatures after preconditioning at $45{ }^{\circ} \mathrm{C}$ for $1 \mathrm{~h}$ (Mishra et al., 2002).

In conclusion, heat preconditioning increased the quality and survival capacity of plants in subsequent continuous heat stress of nonheat-tolerant 'Sizzler Red'. Already existing heat-tolerant traits of 'Vista Red' were enhanced with preconditioning. The higher tolerance levels with and without heat preconditioning for 'Vista Red' suggests that cultivars with thicker, broader leaves and higher stomatal frequency had higher light interception, gas exchange, transpirational cooling, and $\mathrm{CO}_{2}$ fixation. Thus, plants attained higher biomass accumulation to compensate for the heat stress loss. These plants also attained a more rapid canopy cover and were able to maintain healthier leaves and supply photoassimilates to reproductive development and root growth. Selecting for these characteristics could be used to help provide guidelines for breeding heat-tolerant cultivars of salvia and many other ornamental bedding plants.

\section{Literature Cited}

Aston, M.J. 1978. Differences in the behavior of adaxial and abaxial stomata of amphistomatous sunflower leaves: Inherent or environmental? Plant Physiol. 5:211-218.

Bigras, F.J. 2000. Selection of white spruce families in the context of climate change: Heat tolerance. Tree Physiol. 20:1227-1234.

Bonos, S.A. and G.A. Murphy. 1999. Growth responses and performance of kentucky blue grass under stress. Crop Sci. 39:770-774.

Bradford, M.M. 1976. A rapid and sensitive method for the quantitation of microgram quantities of protein utilizing the principle of protein-dye binding. Anal. Biochem. 72:248-254.

Crafts-Brandner, S.J. and R.D. Law. 2000. Effect of heat stress on the inhibition and recovery of ribulose-1, 5-bisphosphatase carboxylase/ oxygenase activation state. Planta 212:67-74.

Deng, Z. and B.K. Harbaugh. 2006. Progress in breeding of disease resistance and stress tolerance in caladium, gerbera and lisianthus. 27th Intl. Hort. Congr. p. 139. (Abstr.)

DeRocher, A.E., K.W. Helm, L.M. Lauzon, and E. Vierling. 1991. Expression of conserved family of cytosolic low molecular weight heat shock protein during heat stress and recovery. Plant Physiol. 96:1038-1047.

Downs, C.A. and S.A. Heckathorn. 1998. The mitochondrial small heat-shock protein protects NADH: Ubiquinone oxidoreductase during heat stress in plants. Federation Eur. Biochem. Soc. Lett. 430:246-250.

Engelke, M.C. 1985. Quality turf in the natural environment enhanced through genetic improvement. U.S. Golf Assn. Green Section Record 23:5-7.

Erwin, J., N. Mattson, and R. Warner. 2003. Fundamentals of flowering in plants: Supplemental lighting and earliness of flowering. University of Minnesota/Minnesota Nursery and Landscape Association, Minnesota Commercial Flower Growers Bul. Aug.:5-8.

Givnish, T.J. 1987. Comparative studies of leaf form: Assessing the relative roles of selective pressures and phylogenetic constraints. New Phytol. 106:131-160.

Gratani, L. and E. Ghia. 2002. Adaptive strategy at the leaf level of Arbutus unedo L. to cope with Mediterranean climate. Flora 197: 275-284.

Griffin, J.J., T.G. Ranney, and D.M. Pharr. 2004. Heat and drought influence photosynthesis, water relation and soluble carbohydrates of two ecotype of redbud (Cercis canadensis). J. Amer. Soc. Hort. Sci. 129:497-502.

Harbaugh, B. and J.W. Scott. 2001. 'Florida Silver': A semi-dwarf heat-tolerant Lisianthus. HortScience 36:988-989. 
Harbaugh, B.K. and Z. Deng. 2006. UF Savanna cultivar group: Eight colors of heat tolerant lisianthus for potted plants. HortScience 41:850-854.

Harndahl, U., R.B. Hall, K.W. Osteryoung, E. Vierling, J.F. Boreman, and C. Sundby. 1999. The chloroplast small heat shock protein undergoes oxidation-dependent conformational changes and may protect plants from oxidative stress. Cell Stress Chaperones 4:129-138.

Huang, B. and J.D. Fry. 1998. Root anatomical, physiological and morphological responses to drought stress for tall fescue cultivars. Crop Sci. 38:1017-1022.

Ismail, A.M., A.E. Hall, and J.D. Ehlers. 2000. Delayed-leafsenescence and heat-tolerance traits mainly are independently expressed in cowpea. Crop Sci. 40:1049-1055.

Jakob, U., M. Gaestel, K. Engel, and J. Buchner. 1993. Small heat shock proteins are molecular chaperones. J. Biol. Chem. 268:1517-1520.

Jiang, Y. and B. Huang. 2000. Effects of drought or heat stress alone and in combination on kentucky bluegrass. Crop Sci. 40:1358-1362.

Jiang, Y. and B. Huang. 2001. Osmotic adjustment associated with drought-preconditioning enhanced heat tolerance in kentucky bluegrass. Crop Sci. 41:1168-1173.

Jiao, J. and B. Grodzinski. 1996. The effect of leaf temperature and photorespiratory conditions on export of sugars during steady-state photosynthesis in Salvia splendens. Plant Physiol. 111:169-178.

Karl, T.R., P.D. Jones, R.W. Knight, G. Kukla, N. Plummer, V. Razuvayev, K.P. Gallo, J. Lindseay, R.J. Charlson, and T.C. Peterson. 1993. A new perspective on recent global warming: Asymmetric trends of daily maximum and minimum temperature. Bul. Amer. Meteorol. Soc. 74:1007-1023.

Kolb, P.F. and R. Robberecht. 1996. High temperature and drought stress effects on survival of Pinus ponderosa seedlings. Tree Physiol. 16:665-672.

Krebs, R.A. and V. Loescficke. 1994. Costs and benefits of activation of the heat-shock response in Drosophila melanogaster. Funct. Ecol. 8:730-737.

Knight, C.A. and D.D. Ackerly. 2003. Small heat shock protein responses of a closely related pair of desert and coastal Encelia. Int. J. Plant Sci. 164:53-60.

Laemmli, U.K. 1970. Cleavage of structural proteins during the assembly of the head of bacteriophage $T_{4}$. Nature 227:680-685.

Lasseigne, F.T., S.L. Warren, F.A. Blazich, and T.G. Ranney. 1998. Heat tolerance in perennial salvias. Proc. Southern Nursery Assn. Res. Conf. 43:442-445.

Lee, G.J., N. Pokala, and E. Vierling. 1995. Structure and in vitro molecular chaperone activity of cytosolic small heat shock proteins from pea. J. Biol. Chem. 270:10432-10438.

Lee, G.J., A.M. Roseman, H.R. Saibil, and E. Vierling. 1997. A small heat shock proteins stably binds heat-denatured model substrates and can maintain a substrate in folding-component state. Eur. Mol. Biol. Organization J. 16:659-671.

Leong, S.K. and C.K. Ong. 1983. The influence of temperature and soil water deficit on the development and morphology of peanuts (Arachis hypogaea L.). J. Expt. Bot. 34:1551-1561.

Mahan, J.R., B.L. McMichael, and D.F. Wanjura. 1997. Reduction of high temperature stress in plants, p. 137-150. In: A.S. Basra and R.K. Basra (eds.). Mechanism of environmental stress resistance in plants. Harwood Academic Publishers. Amsterdam, The Netherlands.
Mishra, S.K., J. Tripp, S. Winkelhaus, B. Tschiersch, K. Theres, L. Nover, and K.D. Scharf. 2002. In the complex family of heat stress transcription factors, HsfA1 has a unique role as master regulator of thermotolerance in tomato. Genes Dev. 16:1555-1567.

Natarajan, S. 2005. High temperatures stress responses of Saliva splendens and Viola $\times$ wittrockiana. Louisiana State Univ., Baton Rouge, PhD Diss.

Natarajan, S. and J.S. Kuehny. 2005. Screening bedding plants for heat tolerance. Louisiana Agr. Winter:18-19.

Nau, J. 1998. Culture by crop, p. 730-733. In: V. Ball (ed.). Ball red book. 16th ed. Ball Publishing, Batavia, IL.

O'Connell, M.A. 1994. Heat shock proteins and thermotolerance, p. 163-184. In: A.S. Basra (ed.). Stress-induced gene expression in plants. Harwood Academic Publishers, Chur, Switzerland.

Perdue, D.O., E.J. Mitcham, and L.G. Neven. 1998. Transient expression of HSC70 in cherry fruit subjected to heat shock. J. Agr. Food Chem. 46:4447-4450.

Prasad, P.V.V., P.Q. Craufurd, and R.J. Summerfield. 1999. Sensitivity of peanut to timing of heat stress during reproductive development. Crop Sci. 39:1352-1357.

Roy, S.K. and H. Nakamoto. 1998. Cloning characterization and transcription analysis of a gene encoding an $\alpha$-crystallin-related small heat shock protein a thermophillic Cyanobacterium cyanochococcus vulcanus. J. Bacteriol. 180:3997-4001.

Senthil-Kumar, M., V. Srikanthbabu, B. Mohanraju, G. Kumar, N. Shivaprakash, and M. Udayakumar. 2003. Screening of inbred lines to develop a thermotolerant sunflower hybrid using the temperature induction response (TIR) technique: A novel approach by exploiting residual variability. J. Expt. Bot. 54:2569-2578.

Thebud, R. and K.A. Santarius. 1982. Effects of high-temperature stress on various biomembranes of leaf cells in situ and in vitro. Plant Physiol. 70:200-205.

Towbin, H., J. Staehelin, and J. Gordon. 1979. Electrophoretic transfer of proteins from polyacrylamide gels to nitrocellulose sheets. Procedure and some applications. Proc. Natl. Acad. Sci. USA 76:43504354.

Turner, I.M. 1994a. Sclerophyll: Primarily protective? Funct. Ecol. 8:669-675.

Turner, I.M. 1994b. A quantitative analysis of leaf form in woody plants from the world's major broadleaved forest types. J. Biogeography 21:413-419.

U.S. Department of Agriculture. 2007. Floricultural crops 2006 summary. U.S. Dept. Agr., Agr. Stat. Serv. Spec. Circ. 6-1 (07). 22 Apr. 2008. <http://usda.mannlib.cornell.edu/usda/current/FlorCrop/ FlorCrop-07-26-2007.pdf>.

Vierling, E. 1991. The roles of heat shock proteins in plants. Annu. Rev. Plant Physiol. Plant Mol. Biol. 42:579-620.

Warner, R.M. and J.E. Erwin. 2002. High temperature differentially reduces flowering and alters morphology of twelve pansy cultivars. 26th Intl. Hort. Congr. p. 479. (Abstr.)

Waters, E.R., G.J. Lee, and E. Vierling. 1996. Evolution, structure and function of the small heat shock proteins in plants. J. Expt. Bot. 47:325-338.

$\mathrm{Xu}, \mathrm{Q}$. and B. Huang. 2000. Growth and physiological responses of creeping bent grass to change in air and soil temperatures. Crop Sci. 40:1363-1368. 